\title{
Corporate Environmental Responsibility: Another Road to Achieve Ecological Civilization and Green B RI
}

\author{
Mengxing $L U$ \\ Assistant Professor, Institute of Environmental and Resources Law, China \\ University of Political Science and Law, Beijing, China \\ mengxing0518@126.com
}

\begin{abstract}
Launched in 2013, the Belt and Road Initiative (BRI) was promoted by the Chinese leadership as an open platform to boost global trade, economic growth and transnational cooperation. It has achieved impressive progress in economic terms. However, a concern that has been voiced by international society is that China is using the BRI host countries as a new 'pollution haven'. As a response, the Chinese government launched a variety of policies and guidelines with the aim of integrating the concept of ecological civilization and green development into the implementation of the BRI. In general, China's position is to require all Chinese companies to observe the local environmental laws and standards wherever they invest and operate. However, the minimum standards set by various environmental regulations of the host countries may not be effective in improving corporate environmental performance, particularly when the environmental standards in those counties are lower and more lenient than those that are in effect in China. The aim of this article is to explore whether the concept of Corporate Environmental Responsibility (CER) could motivate Chinese corporations to strengthen environmental risk management when they are operating and investing in these host countries. It is concluded that CER, as a form of private environmental governance, could provide added value for the implementation of ecological civilization and green development in the BRI but the success of this self-regulatory approach nevertheless calls for governmental intervention under certain circumstances.
\end{abstract}

\section{Keywords}

corporate environmental responsibility - CER - private environmental governance ecological civilization - Belt and Road Initiative - BRI - green development 
Today we are living in a risk society ${ }^{1}$ surrounded by a wide range of economic, social and environmental risks. Among them, environmental risk is regarded as one of the most serious, owing to the potential for environmental degradation and harm to human health. ${ }^{2}$ As important players in modern society, corporations are frequently blamed as the major source of the current environmental crisis, usually as a result of their often-reckless activities in pursuit of economic interest. ${ }^{3}$ In the wake of corporate scandals, such as the Enron scandal ${ }^{4}$ and the Volkswagen emission scandal, ${ }^{5}$ modern corporations have been dubbed as 'Frankenstein monsters' or 'externalizing machines', who are capable of doing evil instead of assuming their responsibilities and serving the interests of society as a whole. ${ }^{6}$

In the age of globalization, the negative environmental impacts of corporations reach beyond geographic borders, giving rise to an enduring debate as to whether the process of globalization leads to a 'race to the top' or a 'race to the bottom. ${ }^{7}$ Particularly, in the wake of several catastrophic environmental incidents caused by multinational enterprises (MNEs), such as the Bhopal Disaster ${ }^{8}$

* This article is supported by the Program for Young Innovative Research Teams in China University of Political Science and Law and the Fund of CUPL on Scientific Research for Young Scholars.

1 The concept of risk society was first introduced by the German sociologist Ulrich BECK. See Ulrich BECK, Risk Society: Towards a New Modernity (SAGE Publications 1992).

2 According to a report of the World Health Organization (wHO), air pollution was deemed to present the greatest environmental risk to health in 2019, with 9 out of 10 people breathing polluted air every day: wHO, 'Ten threats to global health in 2019' (World Health Organization, 2019) <https://www.who.int/vietnam/news/feature-stories/detail/ ten-threats-to-global-health-in-2019>.

3 Joel BAKAN, The Corporation: The Pathological Pursuit of Profit and Power (Constable 2005) 19.

4 Bethany MCLEAN \& Peter ELKIND, The Smartest Guys in the Room: The Amazing Rise and Scandalous Fall of Enron (Penguin 2013).

5 Jack EWING, Faster, Higher, Farther: The Volkswagen Scandal (New York, Norton 2017).

6 BAKAN (n 3) 21 and 6o. There is a long-lasting dispute over the 'purpose of the corporation' which can be traced back to the 1920s and 1930s when an influential debate took place between Adolf Berle and Edwin Dodd. The key issue in this debate was the question whose interest corporations should serve. It remains at the heart of the ongoing CSR discussion.

7 See further David VOGEL, 'Is There a Race to the bottom? The Impact of Globalization on National Regulatory Policies' (2001) 22(1) Tocqueville Review 163-172; Nita RUDRA, Globalization and the Race to the Bottom in Developing Countries: Who Really Gets Hurt? (CUP 2008).

8 The Bhopal Disaster is recorded as the world's worst-ever industrial disaster because of its catastrophic consequences. Following the disaster, the Union Carbide Corporation, an American MNE, was accused of adopting double standards in environmental protection 
and the Deepwater Horizon oil spill, ${ }^{9}$ the potential magnitude of adverse effects on the environment deriving from irresponsible business activities has become a global concern. As a result, a variety of policy instruments have been developed at both national and international levels with the aim of motivating corporations to reduce irresponsible business behaviour, such as the United Nations Global Compact ${ }^{10}$ and the OECD Guidelines for Multinational Enterprises. ${ }^{11}$

This topic is highly relevant in the current Chinese context as today more and more Chinese enterprises are heading abroad in the light of Belt and Road Initiative (BRI). Launched in 2013, the BRI was promoted by the Chinese leadership as an open platform to boost global trade, economic growth and cooperation. ${ }^{12}$ As clearly expressed in President XI Jinping's speech at the opening ceremony of the BRI Forum for International Cooperation in 2017, 'China will actively promote international cooperation through the Belt and Road Initiative. In doing so, we hope to achieve policy, infrastructure, trade, financial and people-to-people connectivity and thus build a new platform for international cooperation to create new drivers of shared development.'13 The implementation of the BRI has achieved impressive progress in several respects. According to official statistics, by the end of July 2019, 136 states and 30 international organizations have signed 195 BRI cooperation agreements and the total trade volumes of Chinese foreign direct investment (FDI) exceeded $\$ 9$ o billion dollars. ${ }^{14}$ From the economic perspective, many people see the opportunities for both China and the host countries located along the six economic corridors of the BRI, including the New Eurasia Land

measures between its homelands and the host country. See further the official website of the International Campaign for Justice in Bhopal at: <https://www.bhopal.net/>.

9 The Deepwater Horizon Oil Spill, caused by вр in the Mexican Gulf, resulted in a severe ecological disaster and was the worst oil spill accident in US history.

10 United Nations Global Compact, 'The Ten Principles of the UN Global Compact' (unglobalcompact.org, undated) <https://www.unglobalcompact.org/what-is-gc/mission/ principles>.

11 OECD, OECD Guidelines for Multinational Enterprises (2011) <http://www.oecd.org/daf/ inv/mne/48oo4323.pdf>.

12 Ministry of Foreign Affairs of China, 'President Xi Jinping Delivers Important Speech and Proposes to Build a Silk Road Economic Belt with Central Asian Countries' (September 7, 2013) <https://www.fmprc.gov.cn/mfa_eng/wjb_663304/zzjg_663340/ dozys_664276/gjlb_66428o/318o_664322/3182_664326/t1076334.shtml>.

13 President XI Jinping, 'Work Together to Build the Silk Road Economic Belt and the 21st Century Maritime Silk Road' (Xinhua Net, 14 May 2017) <http://www.xinhuanet.com/ english/2017-05/16/c_136287878.htm>.

14 The relevant data can be accessed on the Belt and Road Portal <https://eng.yidaiyilu .gov.cn>. 
Bridge, the China-Mongolia-Russia Economic Corridor, the China-Central Asia-West Asia Economic Corridor, the China-Indochina Peninsula Economic Corridor, the China-Pakistan Economic Corridor and the China-BangladeshIndia-Myanmar Economic Corridor. ${ }^{15}$ Given the fact that the majority of countries along the BRI are emerging economies that have an increasing need for infrastructure, the implementation of the BRI could substantially improve that infrastructure, as well as transportation and living conditions for people in the host countries. ${ }^{16}$

Despite the remarkable trade and economic growth, the potential environmental risks associated with implementing the BRI urges caution from both Chinese policymakers and those from the host countries. These risks are predicted to be enormous by reason of the following factors. First, the majority of the BRI projects are related to transport and energy infrastructure, such as railways, roads, ports and energy pipelines, which could easily give rise to environmental pollution and ecological damage, such as greenhouse gas emissions, pollution caused by construction and transportation, and damage to biodiversity of the local ecosystems. ${ }^{17}$ Second, as a result of the broad geographic range, the environmental impacts of the BRI projects could be vast. The situation will become even more problematic where the host countries alongside the BRI economic corridors are emerging markets with higher demands for economic development, but also with ecosystems that are more vulnerable to environmental pollution and ecological damage. In this respect, the unsuccessful investment by Chinese enterprises in the Myitsone Dam in Myanmar sounded a warning bell for other Chinese corporations investing abroad. This billion-dollar project was suspended as a result of intensive pressure from local communities and NGOs concerns regarding the potential risks to wildlife and the ecosystem. ${ }^{18}$

15 Organisation for Economic Co-operation and Development (OECD), China's Belt and Road Initiative in the Global Trade, Investment and Financial Landscape (OECD 2018) <https:// www.oecd.org/finance/Chinas-Belt-and-Road-Initiative-in-the-global-trade-investment -and-finance-landscape.pdf>.

16 XI (n 13).

17 See World Bank, Belt and Road Economics: Opportunities and Risks of Transport Corridors (June 18, 2019) 111-112 <https://www.worldbank.org/en/topic/regional-integration/pub lication/belt-and-road-economics-opportunities-and-risks-of-transport-corridors>.

18 See San Yamin AUNG, 'Thousands to March for Termination of Burma's Myitsone Dam' (The Irrawaddy, 21 March 2014) <https://www.irrawaddy.com/news/burma/thousands -march-termination-burmas-myitsone-dam.html>; see also Matthew BAIRD and Brendon THOMAS, 'Greening the BRI in ASEAN' Chinese Journal of Environmental Law $4(2020) 218-235$. 
The concern of China using the BRI host countries as new 'pollution havens' has arisen from international society. ${ }^{19}$ In this context, it becomes imperative for both Chinese policymakers and Chinese companies to meet the increasing expectations, from both domestic and international sides, for environmentally friendly conduct. The call for greening the BRI is not only desirable but also necessary. As a response, the Chinese government launched a variety of policies and guidelines with the aim of integrating the concept of ecological civilization ${ }^{20}$ and green development into the implementation of the BRI. ${ }^{21}$ The concept of ecological civilization has been promoted by the Chinese leadership as a response to environmental degradation in China and with a view to pursuing sustainable development in the future. In a nutshell, ecological civilization calls for greater conservation of natural resources, lowcarbon development, greater recycling of resources and cultivation of an ecological culture. In 2017, the Chinese government clearly outlined its vision to prioritize the concept of ecological civilization and green development within the promotion of the BRI in the Guidance on Promoting Green Belt and Road (hereinafter the Guidance). ${ }^{22}$ According to this Guidance, Chinese companies operating overseas are explicitly required to pursue green development while seeking profit maximization..$^{23}$ Several approaches have been proposed to achieve this 'win-win' scenario, such as facilitating trade of environmental products and services, enhancing green supply chain management and supporting the development of green finance. ${ }^{24}$ In general, China's position is to require all Chinese companies to observe the local environmental laws and standards wherever they invest and operate. ${ }^{25}$ However, the minimum standards set up by various environmental regulations of the host countries may

19 Xiang CAI, Xiahui CHE, Bangzhu ZHU, Juan ZHAO and Rui XIE, 'Will Developing Countries Become Pollution Havens for Developed Countries? An Empirical Investigation in the Belt and Road' (2018) 198 Journal of Cleaner Production 624.

See Miranda SCHREURS, 'Multi-level Climate Governance in China' (2017) 27(2) Environmental Policy and Governance 163.

21 Mette Halskov HANSEN, Hongtao LI and Rune SVARVERUDA, 'Ecological Civilization: Interpreting the Chinese Past, Projecting the Global Future' (2018) 53 Global Environmental Change 195 .

22 Ministry of Ecology and Environment of China (MEE), Ministry of Foreign Affairs (MFA), Development and Reform Commission (NRDC), and the Ministry of Commerce (моғсом), 'Guidance on Promoting Green Belt and Road' (June 28, 2017) <http:// english.mee.gov.cn/Resources/Policies/policies/Frameworkpi/201706/t20170628_416864 .shtml>.

23 ibid 1.

24 MEE, 'The Belt and Road Ecological and Environmental Cooperation Plan' (‘一带一路”生 态环境保护合作规划) May 2017.

$25 \quad$ ibid 6 . 
not be effective in improving corporate environmental performance and may actually be weaker than those in China.

The aim of this article is to elucidate how Chinese corporations may be motivated to strengthen their environmental risk management when investing overseas, particularly in countries with lower or more lenient environmental standards than China. One approach found in the Guidance is to apply 'international regulations ${ }^{26}$ on economy and trade. Various international treaties or codes do provide a spectrum of specific actions that may encourage environmentally responsible conduct. However, as a typical form of soft law, the weak enforcement of international business regulatory frameworks-also referred as 'global governance deficit' ${ }^{27}$-remains an unresolved issue. What makes the situation even more complicated is the reluctance of nation states to impose regulations on international business activities, not only because of jurisdictional restrictions but also, more importantly, because of the prospect of weakening their international competitiveness. ${ }^{28} \mathrm{MOON}$ and VOGEL have described this phenomenon as the regulatory vacuum of international business. ${ }^{29}$ Moreover, it has been observed that given the significant diversity of the environmental standards among the BRI host countries, the harmonization of environmental standards between China and the host countries could be costly and hence face many formidable challenges. ${ }^{30}$

Another approach, strongly recommended in several government policies and initiatives, is to develop an effective corporate social and environmental responsibility (CSR/CER) framework. ${ }^{31}$ The logic of moving beyond mere compliance with mandatory environmental standards has been widely discussed in the CSR/CER literature. In a nutshell, CER refers to the voluntary adoption of higher or stricter environmental standards than those mandated. ${ }^{32}$ In this sense, CER can be viewed as a type of private environmental governance and as a possible response 'to the failure of national and international business

26 MEE et al, 'Guidance on Promoting Green Belt and Road' (n 22) II (ii).

27 See Jeremy MOON and David VOGEL, 'Corporate Social Responsibility, Government, and Civil Society' in Andrew CRANE, Dirk MATTEN, Abagail MCWILLIAMS, Jeremy MOON and Donald SIEGEL (eds) The Oxford Handbook of Corporate Social Responsibility (ouP 2008) 303-326.

28 ibid 310.

29 ibid.

30 Ben BOER, 'Greening China's Belt and Road: Challenges for Environmental Law' (July 2019) The University of Sydney Law School, Legal Studies Research Paper Series No, $19 / 44<$ https://papers.ssrn.com/sol3/papers.cfm?abstract_id=3420544>.

31 See Section 2 below.

32 Mengxing LU, Corporate Social and Environmental Responsibility: Another Road to China's Sustainable Development (Brill 2018) 44-50. 
regulation: ${ }^{33}$ In other words, CER is expected to play a role in encouraging the business community to contribute to the improvement of environmental quality, especially where governmental regulation may fail. Hence, an important question arises as to how the current policy framework in China will influence the development of CER as an important means of achieving the ambitious goals of ecological civilization and green development in the BRI.

\section{Policy Instruments for Corporate Environmental Responsibility in China}

The concept of CER is not new to Chinese society. In the mid-199os, the idea of CER was introduced to the Chinese market through the global supply chain movement in response to the notorious image of Chinese manufacturing industry as 'sweatshops. ${ }^{34}$ It was strongly opposed by both the Chinese policymakers as well as the business community for several reasons. From their viewpoint, CER was utilized as a form of 'intervention in China's internal affairs' 35 and a 'trade barrier', ${ }^{36}$ with the aim of curtailing the competitiveness of Chinese industries. Moreover, it has been argued by a group of Chinese economists that CER was a luxury for the Chinese companies that they could not afford, since many of them were struggling to survive in the market at that time. ${ }^{37}$

This situation changed dramatically after China's accession to the World Trade Organization (WTO) in 2001. Since then, more and more Chinese companies have begun participating in the international market. In turn, China's economic development has become more deeply integrated with the global economy. ${ }^{38}$ To enhance competitiveness in the global market, it is imperative for the Chinese business community to comply with international rules and standards regarding issues such as trade, labour rights, anti-corruption and environmental protection. In recognition of this, the Chinese government

33 MOON and VOGEL (n 7 ) 309.

34 Lei WANG and Heikki JUSLIN, 'The Impact of Chinese Culture on Corporate Social Responsibility: the Harmony Approach' (2009) 88(3) Journal of Business Ethics 433-451; Li-Wen LIN, 'Corporate Social Responsibility in China: Window Dressing or Structural Change' (2010) 28(1) Berkeley J Int'l L 64.

35 WANG and JUSLIN, ibid, 436.

36 Tang LU and Hongmei LI, 'Corporate Social Responsibility Communication of Chinese and Global Corporations in China' (2009) 35(3) Public Relations Review 191, 202.

37 CsR Asia, 'A Study on Corporate Social Responsibility Development and Trends in China' (2015) 17 .

38 George CHOW, 'Impact of Joining the WTO on China's Economic, Legal and Political Institutions' (2003) 8(2) Pacific Economic Review 105. 
changed its attitude towards CER from a passive approach to a pro-active one. ${ }^{39}$ Indeed, a remarkable increase in the number of the CER-related policies and initiatives has been observed since the beginning of the 21 st century. ${ }^{40}$ In this process, the year 2006 is viewed as a milestone in the development of CER in China. This was when a CER-related provision was integrated into the revised Company Law. ${ }^{41}$ As the first important CER-related law in China, Article 5 of the Company Law stipulates that 'a company shall, when engaging in business activities, abide by the law and administrative regulations, observe social moralities and business ethics, act in good faith, accept the supervision of the government and the public, and undertake social responsibility.'2 According to this provision, corporations are explicitly required to undertake social and environmental responsibility while doing business. ${ }^{43}$ Given its wide application to all types of companies, this provision has exerted far-reaching influence on the development of CER in China. ${ }^{44}$

The amendment to the Company Law triggered the proliferation of CER policies and political campaigns. ${ }^{45}$ Accordingly, a variety of public and private actors have actively participated in the promulgation of CER policies, including the governments at both central and local levels, governmental departments, stock exchanges, and industry associations. For example, the State-owned Assets Supervision and Administration Commission of the State Council (SASAC) issued Guidelines to the State-owned Enterprises Directly under the Central Government on Fulfilling Corporate Social Responsibilities in $2008,{ }^{46}$ which specified the general requirements and specific measures for State-Owned Enterprises (soes) to adopt environmental responsibility,

39 Jingchen ZHAO, Corporate Social Responsibility in Contemporary China (Edward Elgar 2014) 67 .

40 It can be observed that many CER-related initiatives were developed in the first decade of the 21st century, including the Company Law in 2006, the Green Credits Policy in 2007, the Guidelines to the State-Owned Enterprises Directly under the Central Government on Fulfilling Corporate Social Responsibilities in 2008, the Green Securities Policy in 2008 , etc.

41 The Company Law of China was enacted on 29 December 1993.

42 Company Law, article 5.

43 Jianbo LOU and Lei TIAN, 'A Study on Sustainable Companies in P.R. China' (February 2013) University of Oslo Faculty of Law Research Paper No. 2013-05 <https://ssrn.com/ abstract $=2218284>$.

44 Company Law, article 2.

45 The Company Law of China has been revised for four times, in 1999, 2005, 2013 and 2018.

46 SASAC, 'Guidelines to the State-owned Enterprise Directly under the Central Government on Fulfilling Corporate Social Responsibilities' (关于中央企业履行社会责任的指导 意见) 2008 <http://www.sasac.gov.cn/n2588035/n2588320/n2588340/c4426934/content .html>. 
particularly in terms of energy efficiency and environmental pollution control. The then State Environmental Protection Administration (SEPA) also enacted the Measures for the Disclosure of Environmental Information (for Trial Implementation $)^{47}$ with the aim of improving environmental information disclosure of both environmental protection agencies and enterprises. Several years earlier, the two stock exchanges in mainland China, namely the Shanghai Stock Exchange (SSE) ${ }^{48}$ and the Shenzhen Stock Exchange (SZSE), ${ }^{49}$ had also published their CER guidelines, encouraging the listed companies to take on their environmental responsibilities.

As a result of the concerted efforts of the public authorities, the discussion of CER attracted increasing attention from academic circles during this period, substantiated by an increase in the number of publications in relation to CSR or CER topics. ${ }^{50}$ Even so, there are still various problems with the current CER policy instruments. Although a policy signal on CER has been explicitly conveyed by the Chinese legislators and regulators, questions remain about the implementation of CER policies and guidelines by corporations. Also, the absence of standardization regarding environmental performance assessment ${ }^{51}$ means that the outcomes of CER practices cannot be measured and evaluated either by public authorities or third-party agencies. Thus, it may lead to a risk of non-compliance or decoupling compliance by corporations, which means that corporations may claim to be environmentally friendly without making any substantive changes.

As the social and economic costs of environmental degradation are increasingly cause for concern, environmental protection has been given heightened importance on China's policy agenda in recent years. China's vision to prioritize ecological civilization and green development can now be seen in a

47 SEPA, 'Measures for the Disclosure of Environmental Information (for Trial Implementation)' (环境信息公开办法(试行)) May 2008 <https://www.cecc.gov/publica tions/commission-analysis/sepa-issues-measures-on-open-environmental-infor mation>. This Measure was abolished in August 2019.

48 SSE, 'Shanghai Stock Exchange Guidelines on Environmental Information Disclosure by Listed Companies' (上海证券交易所上市公司环境信息披露指引) May $2008<\mathrm{http}: / /$ www.sse.com.cn/lawandrules/sserules/main/listing/stock/c/c_20190228_4727830 .shtml>.

49 szsz, 'Shenzhen Stock Exchange Social Responsibility Instructions to Listed Companies' (深圳证券交易所社会责任指引) September 2006 <http://www.szse.cn/English/ rules/siteRule/t20070604_559475.html>.

50 The author searched the CSR/CER-related literature in the CNKI webinar, which shows a remarkable increase in the number of publications after 2006.

51 Sarah Elena WINDOLPH, 'Assessing Corporate Sustainability Through Ratings: Challenges and Their Causes', (2011) 1(1) Journal of Environmental Sustainability 61. 
wide range of laws, regulations and political campaigns. The insertion of the concept of ecological civilization in the amendments to the Constitution of China in 2018 represents significant progress in this domain. The preamble to the Constitution explicitly stipulates that the State is responsible for promoting the coordinated development of material, political, spiritual, social and ecological civilization. ${ }^{52}$ It was also inserted in the substantive part of the Constitution. Article 89 states: "The State Council exercises the following functions and powers ... (6) to direct and administer economic affairs and urban and rural development, as well as the building of an ecological civilization'. The incorporation of ecological civilization in the Constitution, the cornerstone of China's legal system, sends a strong legal and political signal of the importance of enhancing environmental protection and it is expected to exert far-reaching influence on the development of other legal disciplines. ${ }^{53}$ In addition, Article 9 of the Civil Law Code ${ }^{54}$ prescribes one of the basic principles in China's civil law: 'all private actors, individuals and legal persons shall conduct their activities favourably with regard to the promotion of conservation of natural resources and environmental protection'. Article 9 is known as the 'Green Principle'. The incorporation of the 'Green Principle' in civil law reflects the philosophy of ecological civilization and green development. Some scholars describe this phenomenon as the 'ecologicalization trend of law' or the 'greening trend of law', 55 which indicates that more legal disciplines are beginning to integrate and adopt environmental protection provisions.

As mentioned at the beginning of this article, the potential environmental risks of the в RI projects have raised considerable concerns from the host countries and international society. In 2013, the then Ministry of Environmental Protection (MEP $)^{56}$ and the Ministry of Commerce (MOFCOM) responded by publishing the Environmental Protection Guidelines on Foreign Investment and Cooperation..$^{57}$ This requires Chinese companies operating overseas to comply

$5^{2} \quad$ Preamble to the Constitution of China (2018), para 7.

53 Xiang ZHANG, 'The New Development of the Environmental Constitution and its Normative Interpretation' (2019) 3 The Jurist 9 o.

54 Civil Law Code (中华人民共和国民法通则), Art 9.

55 LYU Zhongmei Research Team, "The Implementation of Green Principles in the Civil Law Code' (2018) 1 China Law 5 .

56 MEP is now the Ministry of Ecology and Environment (MEE); see Jinpeng WANG, 'Reform of China's Environmental Governance: The Creation of a Ministry of Ecology and Environment' (2018) 2(1) Chinese Journal of Environmental Law 112.

57 MEP and моғсом, 'Environmental Protection Guidelines on Foreign Investment and Cooperation' (对外投资合作环境保护指南) February 18，2013 (English translation) <http://english.mofcom.gov.cn/article/policyrelease/bbb/201303/20130300043226 .shtml>. 
with the local environmental standards of host countries. ${ }^{58}$ The close linkage between ecological civilization and the BRI has also been stipulated in several BRI-related initiatives. For example, in 2017, the MEP, together with the Ministry of Foreign Affairs (MFA), Development and Reform Commission (NRDC), and the MOFCOM, issued the Guidance on Promoting the Development of Green Belt and Road. ${ }^{59}$ The Guidance makes clear that the promotion of green development in the BRI should be led by the ideology of ecological civilization and green development. ${ }^{60}$ To better implement the Guidance, the then MEP published the Belt and Road Ecological Environment Protection Cooperation Plan (the Cooperation Plan), ${ }^{61}$ which sets out general requirements and specific measures to reinforce environmental protection. More particularly, the role of corporations in promoting green development in the BRI has been frequently mentioned in several parts of the Cooperation Plan. For example, companies are required to pursue environmental responsibility by strengthening environmental risk management and facilitating environmental information disclosure regimes. ${ }^{62}$ Moreover, industry associations are encouraged to develop codes of conduct concerning environmentally friendly behaviour and to implement specific guidance for the business community. ${ }^{63}$

\section{3}

Challenges for Promoting CER in China

The concerted efforts of the Chinese leadership have resulted in the rapid growth of CER, which has been widely recognized and some positive progress has been achieved in practice. An increasing number of Chinese companies have been engaged in environmentally responsible conduct through various approaches, such as publishing CER reports, improving environmental management systems, or upgrading equipment and technology. ${ }^{64}$ However,

$5^{8}$ ibid article 5: 'Enterprises shall understand and observe provisions of laws and regulations of the host country concerning environmental protection. For projects invested in the construction and operation by enterprises, applications shall be filed with local government for permits with respect to environmental protection in accordance with laws and regulations of the host country.'

59 MEE et al, 'Guidance on Promoting Green Belt and Road' (n 22).

60 ibid 1.

61 MEE, 'The Belt and Road Ecological and Environmental Cooperation Plan' (n 24).

62 ibid 5 and 6.

63 See LU (n 32$) 238$ and 252.

64 GoldenBee, 'GoldenBee Research on Corporate Social Responsibility Reporting in China', December 19, 2017 <http://en.goldenbeechina.com/index.php/Home/Insights/show/ id/68>. 
as argued elsewhere, ${ }^{65}$ the overall level of environmental performance of Chinese companies remains relatively low in comparison with their global counterparts. For example, Chinese enterprises may be ranked low in, or absent entirely from, global ratings or indices for sustainability or environmental performance, such as the Dow Jones Sustainability Index (DJSI). ${ }^{66}$

It is apparent that CER is at an early stage of development in China and that it faces several constraints in improving corporate environmental behaviour. These are related to various issues in China's institutional context, such as the higher level of governmental intervention, the lack of market demand, weak bottom-up demand, limited opportunities for public participation and unclear boundaries between government and business. ${ }^{67}$ This section focuses on the two major challenges from political and economic perspectives.

The first significant challenge derives from the dominant role of the government in directing the discourse of CER in China. The divergence of the CER development model is clearly observed between Europe and China. In the European context, the development of CER is primarily driven by demands from the other stakeholders, such as consumers, investors and NGOs, which is also known as the 'society-led model' or the 'bottom-up' approach. ${ }^{68}$ The effectiveness of the 'society-led' model can be proved by the burgeoning markets of green products and organic food. ${ }^{69}$ These provide good examples as to how consumers can use their purchasing decisions to influence corporations to improve the environmental quality of their products and services.

In contrast to the European context, it has been observed that the Chinese government has been the major driver behind the rapid growth of CER in China by issuing a large number of policies, guidelines and initiatives. This is known as the 'state-led model' or 'top-down approach.' ${ }^{70}$ The official endorsement of CER provides strong incentives for corporations to move towards environmentally responsible conduct because they need to sustain the 'social licence to operate' by reacting to policy signals. ${ }^{71}$ In recent years, because of

$65 \quad$ LU (n 32) $277-278$.

66 Dow Jones Sustainability Index (DJSI), launched in 1999 and based on the cooperation of the Standard \& Poor Dow Jones Indices and Sustainable Asset Management Research, is now widely recognized as one of most influential rating in the field of sustainability.

67 Virginia Harper HO, 'Beyond Regulation: A Comparative Look at State-Centric Corporate Social Responsibility and the Law in China' (2013) 46 Vanderbilt Journal of Transitional Law 436.

68 See HO (n 67).

69 LU (n 32) $137-138$.

$70 \quad \mathrm{HO}(\mathrm{n} 67)$.

71 Wenjing LI and Ran ZHANG, 'Corporate Social Responsibility, Ownership Structure, and Political Interference: Evidence from China' (2010) 94(4) Journal of Business Ethics 634. 
the growing environmental consciousness of civil society, environmental protests have frequently occurred in China. This has become an important source of social upheaval and it poses a significant threat to the ruling legitimacy of the government. For example, the construction of PX oil refinery projects has resulted in large-scale protests in several cities, including Xiamen, Dalian, Kunming and Maoming. ${ }^{72}$ In the fight against environmental pollution, the Chinese leadership has clearly recognized the limitations and weaknesses of the traditional command-and-control regulation. In this context, CER is embraced by the government as an endeavour from the business community to address the regulatory deficit in the field of environmental protection. However, it has been argued that the higher level of government intervention may undermine the effectiveness of CER in improving corporate environmental performance. Some scholars condemn the fact that CER has been employed as a political strategy to pursue political and social goals, while market demand for CER has not been given equal attention. ${ }^{73}$ In the end, this may lead to the blurring of boundaries regarding the respective functions of the public and private sectors. ${ }^{74}$

The dual role of government is more obvious in the specific case of the Chinese sozs. As the backbone of China's economy, soes are at the heart of China's historical transition from a centrally planned economy to a market economy. ${ }^{75}$ In China, soEs are the major force for boosting economic growth and implementing national strategies as well as for maintaining social stability. Not surprisingly, soes also play an important role in the implementation of the BRI and the development of ecological civilization. Accordingly, soes are facing higher expectations from both the government and the public to become leading examples in the domain of environmental protection. ${ }^{76}$ soes undertake greater levels of CER than any other type of business organization in China and they are subject to many CER-related initiatives and guidelines. However, the dual roles of government in the case of soes trigger even more disputes. Although soEs have been granted a certain degree of managerial

72 See eg Luna LIN, 'Residents in Maoming Protest against PX Production', China Dialogue (April 3, 2014), <https://chinadialogue.org.cn/en/pollution/6878-residents-in-maoming -protest-against-px-production/>.

73 See LIN, ibid 65; Qinghua ZHUA and Joseph SARKIS, 'Relationships between Operational Practices and Performance among Early Adopters of Green Supply Chain Management Practices in Chinese Manufacturing Enterprises' (2012) 22(3) Journal of Operations Management 265 .

74 Liangrong ZU and Lina SONG, 'Determinants of Managerial Values on Corporate Social Responsibility: Evidence from China' (2009) 88 Journal of Business Ethics 105.

$75 \quad$ ZHAO (n 39) 65 .

76 ibid. 
autonomy, the government maintains an influential position on soes as both shareholder and regulator. On the one hand, the government, as the largest shareholder, may ask soes to focus on profit maximization. On the other hand, the government, as the supervisor and regulator, may require soEs to provide public services which are traditionally governmental duties. In such circumstances, the government may be accused of diverting wealth to achieve its political goals. ${ }^{77}$

The second challenge is the lack of market incentives for CER. This could result in the risk of decoupling or greenwashing, where corporations may strategically make use of CER to demonstrate symbolic compliance with government initiatives without taking any substantive actions. The risk of greenwashing is widely observed in the domain of environmental information disclosure, where consumers who have special preference for environmentally friendly products make their purchasing decisions based on the information disclosed by producers. ${ }^{78}$ However, the environmental information disclosure mechanism, either through reporting or labelling, could be manipulated easily by corporations for profit maximization. According to the economic model of greenwashing established by LYON and MAXWELL, ${ }^{79}$ corporations make their environmental information disclosure decisions based on a cost-benefit analysis. They could decide to disclose environmental information or withhold it, or they can choose what information they would like to disclose to their consumers. As a result, it will lead to 'a market for lemons', ${ }^{80}$ in which products with genuine environmental quality could be crowded out by the products with poorer environmental quality. From a law and economics perspective, greenwashing is both a market failure and an adverse selection problem which will destroy public trust in the green market and erode the effectiveness of CER in the long run. In this regard, government intervention is still needed to deter greenwashing.

\footnotetext{
77 LI and ZHANG (n 71).

78 Thomas LYON and John MAXWELL, 'Greenwash: Corporate Environmental Information Disclosure under the Threat of Audit' (2011) 20(1) Journal of Economics and Management Strategy 3 .

79 ibid.

8o George AKERLOF, 'The Market for Lemons: Quality Uncertainty and the Market Mechanism' (1979) 84(3) Quarterly Journal of Economics 488.
} 
Given the restricted scope of this article, the possible approaches to promote the success of CER are focused on addressing the two challenges presented in the previous section.

\subsection{The Strategic Values of CER}

According to some surveys, compliance with governmental policies and initiatives ranks as the most important rationale for companies' engagement in CER, while the business case for CER is listed as the least important incentive. The survey results show that the strategic values of CER have not been fully recognized by the Chinese business community and other stakeholders and that there is little appreciation of CER in the market. ${ }^{81} \mathrm{In}$ fact, this is not a phenomenon that only occurs in China. Since its inception, the concept of CER has received enduring criticism from academics and the business community. The position of Milton FRIEDMAN in this paradigm is probably one of the most often-cited arguments against CER. According to FRIEDMAN the only responsibility of business is to increase profits. ${ }^{82}$ In this context, CER was not wanted by the market and business stakeholders, simply because it comes at the expense of corporate profits.

However, another group of scholars argue that there is a business case for CER, which is also known as strategic CER. ${ }^{83}$ In general, the strategic CER hypothesis indicates that under various circumstances there is a market for CER, especially where engagement in CER could generate added value for corporations. First, CER could be used as a marketing strategy for corporations to improve their reputations. ${ }^{84}$ In this case, corporations with better environmental performance could differentiate themselves from their competitors. By doing so, corporations can ensure brand loyalty among consumers and investors who have a special preference for positive environmental attributes, and who are also willing to pay a premium for such a preference. In this case, corporations will be rewarded for being more environmentally friendly. Additionally,

\footnotetext{
$81 \quad$ CSR Asia (n 37) 16-22.

82 Milton FRIEDMAN, 'The Social Responsibility of Business is to Increase its Profits', The New York Times Magazine (September 13, 1970).

83 Elizabeth KURUCZ, Barry COLBERT and David WHEELER, 'The Business Case for Corporate Social Responsibility', in CRANE et al (n 27) 84; Carrie BRADSHAW, 'The Environmental Business Case and Unenlightened Shareholder Value' (2013) 33(1) Legal Studies 141.

84 Marc OLITZKY, 'Corporate Social Performance and Financial Performance: A Research Synthesis' in CRANE et al (n 27) 113-134.
} 
being seen to be actively engaging in CER can help corporations reduce the potential risk of being targeted by NGOs who might use the so-called 'naming and shaming' strategy against irresponsible business conduct.

Second, corporations may have a strong willingness to apply the environmental standards they create to reduce the likelihood of governmental intervention. ${ }^{85}$ This creates the intrinsic motivation for corporations to engage in CER. The advantages of private regulation over public (governmental) regulation is well developed in the law and economics literature, including the higher expertise of the stakeholders, and lower information and organization costs, all of which could become sources of market competitiveness. ${ }^{86}$ In fact, corporations may wish to use good environmental performance to improve their position within the current or future regulatory framework. ${ }^{87}$ For example, corporations with strong records of environmental management will be rewarded by the regulatory authorities with fewer environmental inspections, preferential taxes, and more critical public resources. Moreover, some corporations also use CER to spur future regulation and hence improve their position by being one step ahead of their competitors. ${ }^{88}$ This in particularly so in the field of environmental protection where investments in environmental management or eco-friendly technology in the short term will incur an increase in corporate costs. However, such expenditure could pay off in the long run. For example, this could substantially reduce the possibility of environmental incidents, avoid the potential harm or nuisance to individuals and the environment, or improve energy efficiency.

In contrast to the traditional paradigm that treats CER as an extra expenditure, there are many scenarios where business could do better by doing more in the sphere of environmental protection. Therefore, it is crucial for both the business leaders and the policy makers to broaden their understanding of CER beyond philanthropy and legal compliance.

85 David VOGEL, The Market for Virtue: The Potential and Limits of Corporate Social Responsibility (Brookings Institution Press 2006) 16.

86 James MILLER III, 'The FTC and Voluntary Standards: Maximizing the Net Benefits of Self-Regulation' (1984) 4(3) Cato Journal 897; Niels PHILIPSEN, Regulation of and by Pharmacists in the Netherlands and Belgium: An Economic Approach (Intersentia 2003).

87 Mengxing LU, 'The Chinese Approach to CSR Development: an Analysis of CSRGovernment Relationships in China' (2020) 14(4) International Business Governance and Ethics 386.

88 Forest REINHARDT, Robert STAVINS, and Richard VIETOR, 'Corporate Social Responsibility through an Economic Lens' (2008) 2(2) Review of Environmental Economics and Policy 225. 


\subsection{The Government-Business Relationship in CER}

As mentioned above, a significant divergence between different approaches to CER has been identified in the Western and Chinese contexts. ${ }^{89}$ The development of CER is primarily driven by the private sector in the West. ${ }^{90}$ However, this does not mean that Western governments do not participate in the development of CER. In fact, the European experience suggests that the government can play an important role in supporting and promoting CER. ${ }^{91}$ The main difference between these two approaches lies in how to deal with the interactions between the government and the business community. In this respect, the European Commission sets an example of identifying the respective roles of public authorities and corporations in promoting CER. As clearly prescribed in A Renewed EU Strategy 2011-14 for Corporate Social Responsibility, ${ }^{92}$ companies shall take the lead in this process, while public authorities provide a supporting role through a mix of mandatory and voluntary policy instruments. In this approach, the business community is given more discretion to decide in which way they would like to engage in CER practice, depending on their respective industries and expertise. More importantly, they could identify the key environmental issues that are financially material to their business. On this view, as a type of private environmental governance, CER does not mean that there is no room for public authorities in any circumstances. On the contrary, many problems may impede the effectiveness of CER in improving corporate environmental performance, such as the risk of information asymmetry and the decoupling of regulation and enforcement. Thus, although the development of CER should be primarily through market demand, government intervention is still needed to accompany its success.

\section{5}

\section{Concluding Remarks}

This article has sought to explore the possible approaches to implement China's strategic vision of ecological civilization and green development in the BRI and consider the role of corporations in achieving this goal. As one of

\footnotetext{
$89 \quad$ See Section 3 above.

9o $\operatorname{VOGEL}(\mathrm{n} 7)$.

91 David MILLON, 'Corporate Social Responsibility and Environmental Sustainability', in Beate SJÅFJELL and Benjamin RICHARDSON (eds), Company Law and Sustainability: Legal Barriers and Opportunities (CUP 2015) 35-78.

92 Communication from the Commission to the European Parliament, the Council, the European Economic and Social Committee and the Committee of the Regions, A Renewed EU Strategy 2011-14 for Corporate Social Responsibility, Сом (2011) 681 final.
} 
the important participants of the BRI, on the one hand, corporations are responsible for the creation of environmental risks; on the other hand, they play a critical role in greening the BRI. In recognition of this, the Chinese government encourages companies operating overseas to pursue green development while seeking profit maximization. In this context, CER provides a possible approach for achieving this 'win-win' scenario. From the perspective of environmental governance, as a form of private/self-regulation, CER could play a supplementary role, particularly in the context of an environmental regulation deficit.

Chinese legislators and Ministries have already provided a wide range of policy instruments in relation to CER issues, which have created more favourable conditions to promote the development of CER in China. However, it is clear that at this relatively early stage the development of CER is facing several constraints that may undermine the effectiveness of this self-regulatory approach. Therefore, further reforms are needed to accompany the success of CER in implementing green development in the BRI.

Two suggestions were proposed to boost the development of CER in China. First, it is crucial for both the Chinese enterprises and policymakers to broaden the understanding of the strategic values of CER. Second, it is also critical to identify the respective roles of government and business in the further improvement of the CER policy framework. The fact that CER is primarily a voluntary mechanism does not mean that there is no role for public authorities to play in this process. On the contrary, government intervention is needed to oversee this self-regulation process under certain circumstances. ${ }^{93}$ Finally, with regard to the implementation of the concept of ecological civilization in the context of the BRI, the practice of CER should be promoted by the governments of the host BRI countries with respect to both Chinese corporations as well as the local corporations in those host countries that collaborate and trade with Chinese corporations.

$93 \mathrm{LU}(\mathrm{n} 87)$. 